\title{
Optimization of Face Milling Parameters Considering Wear and Tool Life of Cutters to Improve the Quality, Cost and Power Consumption
}

\author{
Danil Yurievich Pimenov ${ }^{1}$, Munish Kumar Gupta ${ }^{2}$, Ivan Nikolaevich Erdakov ${ }^{3}$, \\ Adel Taha Abbas ${ }^{4, *}$, Mahmoud Sayed Soliman ${ }^{4}$ and Magdy Mostafa El Rayes ${ }^{4}$ \\ 1 Department of Automated Mechanical Engineering, South Ural State University, Lenin Prosp. 76, \\ Chelyabinsk 454080, Russia; danil_u@rambler.ru \\ 2 Department of Mechanical Engineering, Chandigarh University, Gharuan, Punjab, India; \\ munishguptanit@gmail.com \\ 3 Foundry Department, South Ural State University, Lenin Prosp. 76, Chelyabinsk 454080, Russia; \\ wissenschaftler@bk.ru \\ 4 Department of Mechanical Engineering, College of Engineering, King Saud University, P.O. Box 800, \\ Riyadh 11421, Saudi Arabia; solimanm@ksu.edu.sa (M.S.S.); melrayes@ksu.edu.sa (M.M.E.R.) \\ * Correspondence: aabbas@ksu.edu.sa
}

\begin{abstract}
Face milling is a well known commercial process highly used in heavy industries that consumes high amount of power. Besides power issue, modern manufacturing industries are aiming for per part cost reduction keeping the product quality unimpaired. Unexpectedly if the part is rejected in any stage of manufacturing, the cost of manufacturing dramatically increases. Major cause of part rejection is excessive tool wear that imparts poor surface profile or catastrophic tool failure that causes adherence of broken tool debris onto machined surface. Furthermore, the tool wear is associated with sliding distance (frictional distance) and the tool life quantifies the cost of tools. As such, from the perspective of manufacturing industries it is imperative to optimize the surface quality parameter, cost of part, power consumption, and material removal - this is exactly what is accomplished here. By this work, it is possible to conserve power consumption, produce parts with lower cost, manufacture with uncompromising surface quality and enhanced material removal rate. Moreover, as intermediate factors of interest, the influences of sliding distance, tool life and tool flank wear on the overall machining performance are evaluated. The multi-objective optimization by Grey Relational Analysis (GRA) revealed that for improved product performance and fast manufacturing (case 1) optimum results are: feed per tooth $f_{z}=0.25 \mathrm{~mm} /$ tooth, cutting speed $v_{c}=392.6 \mathrm{~m} / \mathrm{min}$ and cutting length $l=0.5 \mathrm{~mm}$; for resource conservation (case 2) the optimum results are: feed per tooth $f_{z}=0.125 \mathrm{~mm} /$ tooth, cutting speed $v_{c}=392.6 \mathrm{~m} / \mathrm{min}$, cutting length $l=0.5 \mathrm{~mm}$.
\end{abstract}

Keywords: Face milling; Cost saving; Power consumption; Surface quality; Tool wear.

\section{Introduction}

In this growing world, the demand of energy efficient manufacturing processes is rapidly increasing because of the strict environmental concerns. However, the power consumption and cost issues in manufacturing processes are two important factors from the perspective of machining system that directly oblige the manufacturer to search for environmental friendly processes. In one example, the highly developed country i.e., USA itself contributes $11.7 \%$ towards the higher value of Gross Domestic Product (GDP) only from the different manufacturing industries. In addition, the high environmental acts are strictly regulated and implemented in the manufacturing industries that allow the use of innovative and practical approaches in different manufacturing processes. 
Currently, the established sustainable strategies i.e., optimization and modelling of process parameters are well-implemented in the industries to control the power and cost factors. For instance, if the process parameters are ideally optimized, then the total energy is saved up to certain extent. Same scenario is noted by the Liu et al. in the machining of Inconel alloy and it was found that with the modelling of machining processes the significant amount of environmental burdens have been reduced. Similarly, the various reports related to the energy consumption throughout the world are intensively available in the literature. In the first report of USA, the energy consumed by the manufacturing industries is nearly equal to the $31 \%$ out of total energy consumed in whole country [1]. On same context, the estimation of Green house gases and its effect on environment is noted to be $19 \%$. In another report, the energy consumed around the globe in 2010 is found to be 510 QBtu with an annual increment of $2 \%$. With these reports, it has been noticed that the power consumption and cost are the significant factors that exhaustively affect the machining process from environmental point of view. Therefore, the main objective of this paper is to perform an experimental study especially related to two research objectives, i.e., power consumption measurement and cost estimation of face milling process.

Face milling is a highly efficient type of machining process [2-4], widely used in manufacturing flat surfaces [5, 6]. In face milling, a considerable number of mill teeth are involved at the same time, which leads to a significant increase in the cutting force [7, 8]. At the same time, face milling consumes a significant amount of energy [9], which in part is caused by a larger tooth wear area [10]. Besides, tool wear increases along with the sliding distance (friction distance), and tool life determines the tool cost [11]. In modern manufacturing, minimizing machining cost per workpiece is very important $[12,13]$. Just as important is ensuring a crucial characteristic of flat-surfaced workpieces: surface roughness $\mathrm{Rz}[14,15]$. It is therefore important in designing face milling operations to ensure the design surface roughness and minimize the power consumption and cost of machining at the same time. This approach allows for saving resources in manufacturing the end item.

Minimizing the machining energy has been a key aspect of manufacturing for sustainability due to the higher rising price of energy as well as the requirement to reduce carbon emission. Henceforth, researchers have explored many strategies to minimize the machining energy (i.e. power) consumption. For instance, Hu et al. [16] strategically optimized the machining sequence to minimize the machine tool energy consumption. The machining scheme composed of milling and drilling operations on C45 steel. They have claimed that selecting the apt route can significantly reduce the power consumption in machining. In another paper, Hu et al. [17] attempted to reduce the energy consumption in machining for tool change and tool path; a $28.6 \%$ reduction is noticed in energy consumption caused by feature transitions. Even, that optimum change caused $27.95 \%$ reduction in machining time - an extra benefit. Considering the extreme importance of energy consumption in machining, Li et al. [18] formulated specific energy consumption and power models for face milling operations with reliability above $96 \%$. These models were formulated in terms of MRR and cutting speed, and authors claimed that those models are useful for estimation of power without measurement. Aramcharoen and Mativenga [19] identified the critical factors to energy modeling and influence of tool wear on energy intensity during machining. Their developed models predicted energy at $95 \%$ accuracy. They have also stressed that the reduction of tool wear can play effective role in reducing the energy consumption. An intelligent model was proposed by Garg et al. [20] for conserving the energy consumption in milling machining. They have employed the advanced evolutionary algorithm i.e. multi-gene genetic programming technique. Another energy optimization study was reported by Albertelli et al. [21] with the novelty that they considered, in their model, the energy consumed by the auxiliary systems of a machine tool in face milling process. In fact, the authors have correlated the energy parameters with cutting parameters. Most notably, the influence of changes in tool wear in the machining process was incorporated in the model too. They have emphasized that the appropriate selection of process parameters are imperative to reduce the energy and time. On the other hand, Garg et al. [22] studied and modeled the tool life and power consumption for machining using three advanced modeling methods. The inputs to the models 
were cutting speed, nose radius, cutting depth and feed rate. Then statistical comparison was conducted to suggest the best model - the genetic programming model. However, in the above studies the cost of machining was not considered.

Li et al. [12] conducted the study based on the hypothesis that the energy consumption and cost-incurred due to single pass and multiple-pass face milling is different. When they completed the research they claimed that the optimization of the electrical energy does not necessarily optimize the cost function. Hence, the multi-objective optimization was required which they have performed. They have even identified that the trade-off is required between cost and energy. Shin et al. [23] have advanced the energy prediction and optimization knowledge by developing and implementing on-line optimization so that real-time process control can be accomplished to minimize energy consumption. Deng et al. [24] in their study attempted to reduce the energy consumption by milling machine tool. They have performed the optimization within the constraints of surface roughness, tool life and maximum power of machine tool. The target was to find minimum specific cutting energy and minimum processing time where the former one was reduced by $32.07 \%$ and later one was reduced by $34.11 \%$. It is observable that the studies are hardly considering the influence of tool wear on the power consumption.

Shi et al. [25] proposed a novel approach to modeling the energy consumption in milling machining by taking into account the influence of tool wear on the energy consumption. The author reported that the tool wear can be estimated from the power consumption and vice versa. For turning operation, Lv et al. [26] employed three different approaches such as cutting force, specific energy and exponential approach to model the material removal energy. They have claimed that based on the experimental validation the cutting force based method showed best accuracy. Altıntaş et al. [27] estimated the theoretical energy consumption for milling operation. Later, they have optimized the control parameters to optimize the energy consumption. Wang et al. [13] performed multi-response optimization for reducing the cost as well as the energy consumption using evolutionary algorithms for face milling.

A comprehensive optimization study was conducted by Yang et al. [28] for face milling. They have optimized cost of production, time, and rate of profit while maintaining the constraints of force, power, speed and feed and surface roughness. Yang et al. [29] employed advanced modeling technique i.e. Gene expression programming to model the energy consumption in face milling.

Today, studies dedicated to different machinability aspects of face milling are available. However, there is scarcity of study regarding the sustainability achievement in machining by power consumption reduction and cost performance improvement. For instance, Sales et al. [30] investigated the performance of MQL in milling of AISI 4140 steel by considering surface roughness values, flank wear and tool life as an input process parameters. Singh et al. [31] performed the milling experiments on Inconel-718 and the performance in terms of tool wear with respect to the milling process parameters were evaluated by evolutionary algorithm. On same content, Gupta et al. [32] applied the two evolutionary algorithm for optimizing the turning parameters under MQL conditions. Then, Siller et al. [33] discussed the influence of specially designed carbide tool on the performance (surface quality and tool life) of AISI D3 steel during face milling operation. Cui and Zhao [34] examined the important machining indices in terms of tool wear mechanism, chip and surface characteristics in high speed face milling of AISI H13 steel In another face milling operation of Ti-10V-2Fe-3Al (Ti-1023), Houchuan et al. [35] discussed the effect of cutting speeds along with the average flank wear values on surface characteristics, defects of machining, microhardness, and microstructure variations values. Similarly, the influence of damaged inserts on surface roughness values during high speed face milling of 17-4 PH steel was investigated by Liu et al. [36]. It is appreciable that general machinability aspects are studied by the above researchers. Some critical aspects such as cost, quality of product, and power consumption are missing in many studied. This fact encouraged authors to pursue this comprehensive study.

At present, many researchers use advanced modeling techniques to study surface roughness in face milling. Bruni et al. [37] implemented the artificial neural network technique to analyze the effect of lubri-cooling techniques on surface roughness values during face milling of AISI $420 \mathrm{~B}$ steel. 
Sahu and Andhare [38] used the response surface methodology for estimation of power, productivity, tool wear and surface roughness in high speed milling of Ti6-AL-4V alloy. Siwawut et al. [39] investigated the machining behavior and wear properties of Co-WC coated inserts in dry face milling of cast iron. Studies use artificial intelligence to establish the correspondence between face milling parameters and the resulting surface roughness taking into account tool wear. However, no qualitatively studies of the influence of face milling parameters on factors such as surface roughness, tool life, cutting power, and machining cost have been conducted in the literature. Managing cutting power and minimizing cost per workpiece enable us to promote sustainable manufacturing. It is also important to take into account tool life and flank wear that are affected by the cutting parameters.

The aim of this study is therefore to provide for the design surface roughness while decreasing the cutting power and minimizing face milling costs at the same time.

\section{Methodology}

In order to save resources on manufacturing the end product in face milling it is very important to provide for the design surface roughness while at the same time minimizing the power consumed by the cutting operation as well as machining cost. It is also important to take into account the influence of tool wear on these processes.

\subsection{Experimental conditions}

For complex evaluation of surface roughness and minimizing the power consumed by the cutting operation as well as machining cost in face milling experimental studies have been conducted for various tool flank wear values. To this end, machining of a workpiece of 45 steel (the composition of high quality structural carbon steel 45 in accordance with the Russian national state standard (GOST) 1050-99: silicon $\mathrm{Si}-0.17 \ldots 0.37 \%$, carbon C - 0.42...0.5\%, magnesium $\mathrm{Mn}-$ $0.5 \ldots 0.8 \%$, chrome $\mathrm{Cr}$ - below $0.25 \%$, other iron $\mathrm{Fe}$ ) was conducted. For machining of a workpiece with the dimensions Length $L=200 \mathrm{~mm}$, Width $B=75 \mathrm{~mm}$, Height $H=100 \mathrm{~mm}$ without cooling, a SF15 (6C12) vertical mill (LSZ, Lugansk, Ukraine) (Fig.1) was used. The parameters of the cutting tool were as follows: cutting surface material (pentagonal cutter) - T5K10 (the composition of the hard T5K10 alloy of the titanium tungsten cobalt group in accordance with GOST 3882-74 is as follows: tungsten carbide $\mathrm{WC}-85 \%$, titanium carbide TiC $-6 \%$, cobalt $\mathrm{Co}-9 \%$ ); mill diameter: $D=125$ mm; main cutting edge angle: $k_{r}=60^{\circ}$; side cutting edge angle: $k_{r 1}=12^{\circ}$; cutting angle: $\gamma=15^{0}$; relief angle: $\alpha=8^{0}$; number of mill teeth: $z=1$; cutting edge pitch angle: $\lambda=0$. The workpiece hardness was measured at HB 190 using a TB 5004-03 Brinell hardness tester (Tochpribor, Ivanovo, Russia). The reference guide is used to select the input process parameters for machining process, as tabulated in Table 1.

Table 1. Cutting parameters for various stages of face milling.

\begin{tabular}{|c|c|c|c|c|c|}
\hline No. & $\begin{array}{c}\text { Face milling } \\
\text { stage }\end{array}$ & $\begin{array}{c}\text { Milling depth, } a_{p}, \\
\text { mm }\end{array}$ & $\begin{array}{c}\text { Feed per tooth, } f_{z}, \\
\mathrm{~mm} / \text { tooth }\end{array}$ & $\begin{array}{c}\text { Cutting speed, } v_{c}, \\
\mathrm{~m} / \mathrm{min}\end{array}$ & $\begin{array}{c}\text { Spindle rotation } \\
\text { speed, } n, \text { rpm }\end{array}$ \\
\hline 1 & Finishing & 1 & 0.125 & 392.6 & 1000 \\
\hline 2 & Finishing & 1 & 0.16 & 392.6 & 1000 \\
\hline 3 & Semi-finishing & 1 & 0.25 & 392.6 & 1000 \\
\hline 4 & Semi-finishing & 1 & 0.25 & 247.3 & 630 \\
\hline 5 & Initial & 1 & 0.32 & 196.3 & 500 \\
\hline
\end{tabular}

Surface roughness Rz was measured using a profilometer Абрис-ПМ7.0 (Abris-PM7.0) (GCI SI VNIIMS, Moscow, Russia). The readings were taken for the base length $L^{\prime}=0.4 \mathrm{~mm}$ at the start, the middle, and the end of the pass of the mill. Every experiment had therefore $3 \times 5$ iterations $(k=15)$.

The flank wear values as well as machined surface values were noted after each pass of the mill. This way, the experimental points of surface roughness were obtained for various flank wear areas and face milling parameters. Statistical processing was then carried out on the experimental data to 
achieve the design statistical reliability of 0.95 . The average values of the measured parameter were established based on the data from 5 experiments. Sampling variance was selected as the unbiased estimate of the general dispersion. Homogeneity of the sampling variance was checked using the Cochran's Q test.

Fig.1 includes the photos of the flank tooth of the face mill and the machined surfaces after the first and the second pass of the tool.

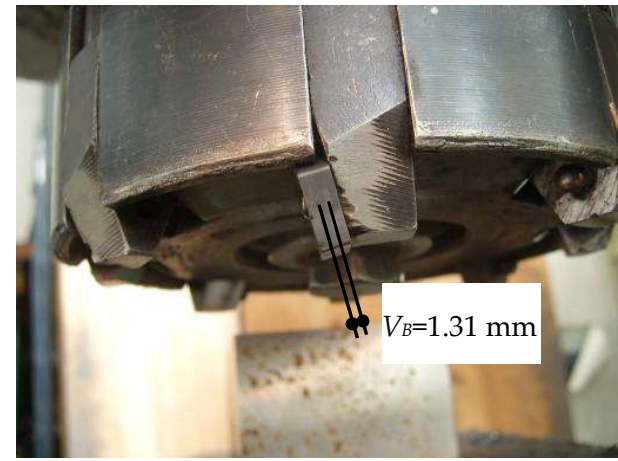

(a)

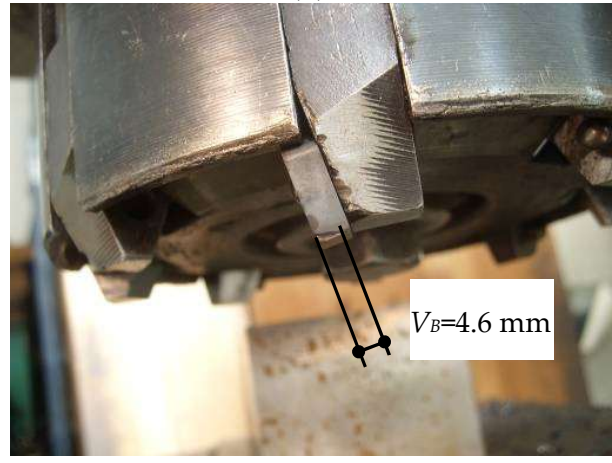

(c)

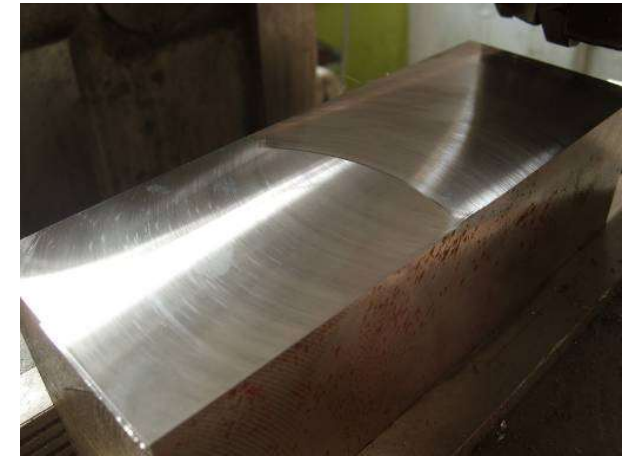

(b)

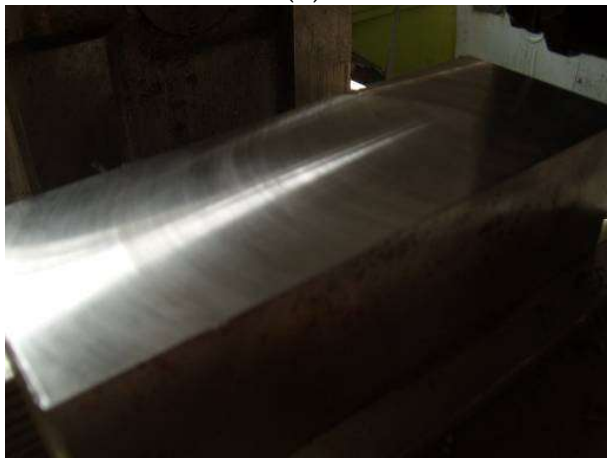

(d)

Fig. 1. Left: flank wear of the mill tooth; right: machined surface of the workpieces at the milling depth $a_{p}=1.0 \mathrm{~mm}$; feed $f_{z}=0.125 \mathrm{~mm} /$ tooth; cutting speed $v_{c}=392.6 \mathrm{~mm} / \mathrm{min}$; Spindle rotation speed of the mill $n=1.000 \mathrm{rpm}$ : (a) Face milling cutter (First pass $V_{B}=1.31 \mathrm{~mm}$ ); (b) Machined part (First pass $V_{B}=1.31 \mathrm{~mm}$ ); (c) Face milling cutter (Second pass $V_{B}=4.6 \mathrm{~mm}$ ); (d) Machined part (Second pass $V_{B}=4.6$ $\mathrm{mm})$.

Table 2 lists the experimental and estimated data for the cutting parameters presented in Table 1. 
Table 2. Experimental and estimated data for various stages of face milling.

\begin{tabular}{|c|c|c|c|c|c|c|c|c|c|c|}
\hline \multirow{2}{*}{$\begin{array}{l}\text { Exp. } \\
\text { No. }\end{array}$} & \multicolumn{6}{|c|}{ Input parameters } & \multicolumn{4}{|c|}{ Output parameters } \\
\hline & $\begin{array}{c}\text { Feed } \\
\text { per } \\
\text { tooth, } \\
f_{z}, \\
\text { mm/to } \\
\text { oth }\end{array}$ & $\begin{array}{c}\text { Cutti } \\
\text { ng } \\
\text { speed, } \\
v_{c}, \\
\mathrm{~m} / \mathrm{mi} \\
\text { n }\end{array}$ & $\begin{array}{c}\text { Cutti } \\
\text { ng } \\
\text { Lengt } \\
\text { h, } l \text {, } \\
\text { mm }\end{array}$ & $\begin{array}{l}\text { Slidin } \\
\mathrm{g} \\
\text { distan } \\
\text { ce, } l_{s}, \\
\mathrm{~m}\end{array}$ & $\begin{array}{c}\text { Process } \\
\text { ing } \\
\text { time } \\
\text { (Tool } \\
\text { life), } T^{\prime} \text {, } \\
\text { min }\end{array}$ & $\begin{array}{c}\text { Flank } \\
\text { wear, } \\
V_{B}, \\
\text { mm }\end{array}$ & $\begin{array}{c}\text { Roug } \\
\text { hness, } \\
R z, \\
\mu \mathrm{m}\end{array}$ & $\begin{array}{l}\text { The cost } \\
\text { price of } \\
\text { processi } \\
\text { ng one } \\
\text { part, } C \\
\$\end{array}$ & $\begin{array}{c}\text { Cutti } \\
\text { ng } \\
\text { powe } \\
\text { r, } P_{c} \\
\text { kW }\end{array}$ & $\begin{array}{c}\text { Material } \\
\text { removal } \\
\text { rate } \\
(\mathrm{MRR}), \\
10^{3} \cdot \mathrm{mm}^{3} / \\
\text { min }\end{array}$ \\
\hline 1 & 0.125 & 392.6 & 5 & 0 & 0 & 0 & 3.2 & 320.000 & 1.531 & 49.1 \\
\hline 2 & 0.125 & 392.6 & 200 & 128.6 & 1.64 & 1.2 & 3.4 & 10.355 & 2.407 & 49.1 \\
\hline 3 & 0.125 & 392.6 & 400 & 257.2 & 3.28 & 3.6 & 4.5 & 6.358 & 4.038 & 49.1 \\
\hline 4 & 0.16 & 392.6 & 5 & 0 & 0 & 0 & 3.7 & 320.000 & 1.930 & 62.8 \\
\hline 5 & 0.16 & 392.6 & 200 & 100.5 & 1.28 & 1.35 & 3.9 & 10.355 & 2.911 & 62.8 \\
\hline 6 & 0.16 & 392.6 & 400 & 201 & 2.56 & 4.5 & 4.8 & 6.357 & 5.019 & 62.8 \\
\hline 7 & 0.25 & 392.6 & 5 & 0 & 0 & 0 & 4.1 & 320.000 & 2.970 & 98.2 \\
\hline 8 & 0.25 & 392.6 & 200 & 64.3 & 0.82 & 1.45 & 4.6 & 10.355 & 4.045 & 98.2 \\
\hline 9 & 0.25 & 392.6 & 400 & 128.6 & 1.64 & 5 & 6.5 & 6.356 & 6.385 & 98.2 \\
\hline 10 & 0.25 & 247.3 & 5 & 0 & 0 & 0 & 4.4 & 320.000 & 1.785 & 61.8 \\
\hline 11 & 0.25 & 247.3 & 200 & 64.3 & 1.3 & 1.25 & 4.9 & 10.089 & 2.351 & 61.8 \\
\hline 12 & 0.25 & 247.3 & 400 & 112.53 & 2.28 & 2.2 & 5.5 & 5.832 & 2.728 & 61.8 \\
\hline 13 & 0.32 & 196.3 & 5 & 0 & 0 & 0 & 6.2 & 320.000 & 1.755 & 62.8 \\
\hline 14 & 0.32 & 196.3 & 200 & 50.3 & 1.28 & 0.8 & 6.4 & 9.570 & 2.068 & 62.8 \\
\hline 15 & 0.32 & 196.3 & 400 & 100.6 & 2.56 & 1.75 & 6.9 & 5.571 & 2.357 & 62.8 \\
\hline
\end{tabular}

\subsection{Calculations for various stages of face milling}

Sliding distance, $l_{s}$, is determined by the formula (1):

$$
l_{s}=(D s l \cdot l) /\left(1000 \cdot f_{z}\right),
$$

where $D_{s l}$ is the length of the tooth mill sliding trajectory $\left(D_{S l}=80.4 \mathrm{~mm}\right)$.

Processing time (tool life) $T^{\prime}$ is determined by the formula (2):

$$
T^{\prime}=\left(L+l_{1}\right) /\left(n \cdot z \cdot f_{z}\right),
$$

where $l_{1}$ is the allowance length $\left(l_{1}=5 \mathrm{~mm}\right) ; f_{z}$ - feed per tooth; $z$ - number of mill teeth; $n$-Spindle rotation speed.

The following formula (3) is used to evaluate the cost of one part i.e., $C_{i}$ :

$\left.C_{i}=\left[\left(C_{M h} \cdot T^{\prime}\right)+\left(C_{\text {Toolmin }} \cdot T^{\prime}\right)+C_{w}\right)\right] \cdot l / L$

Where $T^{\prime}$ represents the time of machining i.e., $T^{/}=(L+l 1) /\left(n \cdot z \cdot f_{z}\right), \quad n=(1000$. $\left.v_{c}\right) /(3.141 \cdot D), C_{M h}$ termed as the machining cost/hour i.e., (CФ15 (6C12)) $\left(C_{M h}=\$ 4\right)$, tool holder cost i.e., $\left.C_{\text {Toolh }}=\$ 50\right)$, tool holder life i.e., $\left(L T_{T o o l}=T \cdot 5\right.$ Year 365 Day $\cdot 24$ hour $=T$. $43,800 \mathrm{~min})$, tool inserts cost i.e., $\left(C_{I n}=\$ 3.5\right), k^{\prime}$ - setup insert $\left(k^{\prime}=5\right)$; z represents the cutting edge number i.e., $(z=1)$, workpiece per unit cost i.e., $\left(C_{w}=\$ 8\right)$, T represents as tool life, tool cost $/ \mathrm{min}$ i.e., CToolmin $=[(\mathrm{CIn} \cdot z) /(T \cdot k /)]+($ CToolh $\cdot$ LTToolh $))$

The initial and final values used to estimate the cost are prescribed in Table 3. 
Table 3. Initial and calculated values of the parameters for determining the cost price of processing one part.

\begin{tabular}{|c|c|c|c|c|c|c|c|c|c|c|c|}
\hline $\begin{array}{c}\text { Machinin } \\
\text { g Length } \\
\text { Section, } l \text {, } \\
\text { mm }\end{array}$ & $\begin{array}{c}\text { Allowanc } \\
\text { e length, } \\
l_{1, \mathrm{~mm}}\end{array}$ & $\begin{array}{c}\text { diameter } \\
\text { of cutter, } \\
D, \mathrm{~mm}\end{array}$ & $\begin{array}{l}\text { Tool } \\
\text { Life, } \\
T, \\
\text { min }\end{array}$ & $\begin{array}{c}\text { Cost of } \\
\text { Machini } \\
\text { ng } \\
\text { /hour, } \\
C_{M h, \$}\end{array}$ & $\begin{array}{c}\text { Cost of } \\
\text { Tool } \\
\text { holder, } \\
\text { CToolh, \$ }\end{array}$ & $\begin{array}{c}\text { Life time } \\
\text { of Tool } \\
\text { holder, } \\
\text { LT Toolh, } \\
\text { min }\end{array}$ & $\begin{array}{c}\text { Cost } \\
\text { of } \\
\text { Insert, } \\
C_{I n,} \$\end{array}$ & $\begin{array}{c}\text { Setup } \\
\text { Insert, } \\
k\end{array}$ & $\begin{array}{c}\text { Number } \\
\text { of teeth, } \\
z\end{array}$ & $\begin{array}{c}\text { Cost of } \\
\text { tool } \\
\text { minute, } \\
C_{\text {Toolmin }} \$\end{array}$ & $\begin{array}{c}\text { Cost of } \\
\text { one } \\
\text { workpie } \\
\text { ce, } C_{w}, \$\end{array}$ \\
\hline 200 & 5 & 125 & 3.28 & 4 & 50 & 143664 & 3.5 & 5 & 1 & 0.214 & 8 \\
\hline 200 & 5 & 125 & 2.56 & 4 & 50 & 112128 & 3.5 & 5 & 1 & 0.274 & 8 \\
\hline 200 & 5 & 125 & 1.64 & 4 & 50 & 71832 & 3.5 & 5 & 1 & 0.428 & 8 \\
\hline 200 & 5 & 125 & 2.93 & 4 & 50 & 128334 & 3.5 & 5 & 1 & 0.239 & 8 \\
\hline 200 & 5 & 125 & 3.84 & 4 & 50 & 168192 & 3.5 & 5 & 1 & 0.183 & 8 \\
\hline
\end{tabular}

Cutting power, $P_{c}$, is determined by the formula (4) [40]:

$$
\begin{gathered}
P_{c}=\left(K_{1} \cdot f_{z} \cdot R_{m i} \cdot \tan k_{r} \sum_{i=1}^{z_{w}} \int_{a}^{b} \frac{\sigma_{i}}{\sin \Phi} \cdot \cos \beta \cdot \sin \psi_{i} \cdot \cos k_{r} \cdot d l+\right. \\
+\frac{R_{m i} \cdot f \cdot \sigma_{i}}{\cos k_{r}} \cdot \sum_{i=1}^{z_{w}} \int_{a /}^{b /}\left(K_{2} \cdot V_{B}+K_{3} \cdot \frac{f_{z}}{2} \cdot\left(1-e^{-2 \cdot V_{B} / f_{z}}\right) \cdot d l\right) \cdot \frac{\pi \cdot D \cdot n}{1000^{\prime}}
\end{gathered}
$$

Where, $K_{1}=\frac{\sqrt{3.25}}{\sqrt{3}}=1.08$ is the a coefficient that represents the ratio of normal cutting force and shear force components [41]; $K_{2}=0.41 \& K_{3}=0.59$ described as the coefficient of horizontal asymptote and the degree of the damping exponents [42], $a /$ is equal to the absence of a portion of the radius section on the top of the tooth and is equal to $R_{m i}\left(1-\cos k_{r}\right)$ in the presence of that portion [41]; b/ is equal to ap [41]; $k_{r}$ is the angle of cutting edge; ap is the depth of cut; fz is feed per tooth; $f$ is the friction worked stock ratio on the flank surface of the mill tooth cutting point; $\beta$ is the angle of action; $\Phi$ is the angle of shear ; $\sigma_{i}$ is stress intensity [43] (the intensity of stress is a function of the intensity of strain, $\varepsilon$, the strain rate, $\dot{\varepsilon}$, and the temperature, $T^{0}$, of the material: $\sigma_{i}=$ $f\left(\varepsilon, \dot{\varepsilon}, T^{0}\right) ; d l$ is the elemental length of the cutting edge; $V_{B}$ is the flank wear on the tool $[41,42,44] ; \psi_{i}$ - is the angular coordinate of the ith tooth; and, $i=x, y, z$ represent each axis of the tool coordinate system.

Material removal rate, MRR, is determined by the formula (5):

$$
\operatorname{MRR}=f_{z} \cdot z \cdot v_{c} \cdot a_{p} .
$$

Formulae (1-5) were used to determine the values of the parameters listed in table 2.

\subsection{Optimization by Grey Relational Analysis}

The optimization by the Grey Relational Analysis (GRA) is performed by considering the optimization problem as a 'Multi-objective Optimization'. Whenever more than one response is optimized GRA stands out as an effective method to solve the optimization. In the current study, the surface roughness, part processing cost, cutting power, and material removal rate are granted as the responses - in total four responses. GRA method combines these four responses into a single function, and then optimizes the unified function. In manufacturing region, numerous studies are reported using GRA method. This method works in three modes depending on the target to the objective functions: minimization, maximization, and simultaneous maximization and minimization. Following steps are accounted:

I. Preprocessing of data: The surface roughness, part processing cost, cutting power, and material removal rate have different scale of magnitudes. Before proceeding ahead, it is imperative to convert different scales into a single scale, from 0 to 1 . This is done by 
normalization following Eq. 6 (minimization is the target) and Eq. 7 (maximization is the target).

$$
\begin{aligned}
& y_{i}(k)=\frac{\max x_{i}(k)-x_{i}(k)}{\max x_{i}(k)-\min x_{i}(k)} \\
& y_{i}(k)=\frac{x_{i}(k)-\min x_{i}(k)}{\max x_{i}(k)-\min x_{i}(k)}
\end{aligned}
$$

II. Here, the experimental data (original) is indicated by $x_{i}(k)$, the normalized preprocessed data is represented by $y_{i}(k)$, also the maximum and minimum values are presented by $\max x_{i}(k)$ and $\min x_{i}(k)$, respectively.

III. Grey relational coefficient: Next, the grey relational coefficient, which defines the relation of experimental value and ideal value, is calculated using Eq. 8.

$$
\vartheta_{i}(k)=\frac{\Delta_{\min }+\zeta . \Delta_{\max }}{\Delta_{0 i}(k)+\zeta . \Delta_{\max }}
$$

IV. Here, the deviation sequence is presented by $\Delta_{0 i}(k)$. Following relations are used to present parameters of deviation sequence. Also, the distinguishing constant $\zeta$ can have value within $0-1$. For the current study, mid-value 0.5 is taken for further calculation.

$$
\begin{aligned}
& \Delta_{0 i}(k)=\left|y_{o}(k)-y_{i}(k)\right| \\
& \Delta_{\text {min }}=\min _{\forall i} \cdot \min _{\forall k} \cdot \Delta_{0 i}(k) \\
& \Delta_{\max }=\max _{\forall i} \cdot \max _{\forall k} \cdot \Delta_{0 i}(k)
\end{aligned}
$$

V. Grey relational grade: As mentioned earlier, the multiple responses are combined to single function i.e. Grey relational grade (GRG). The grey relational coefficients are merged into GRG. The conversion is associated with particular weight values for each response. The typical calculation scheme for GRG is shown in Eq. 9. Depending on the manufacturer's requirements, the weight value changes. In fact, controlling of weights to responses controls the ultimate optimum levels of parameters. For instance, in our current research, two different sets of weight values are accounted to address the technological performance as well as conservation of resources. The details are discussed later.

$$
\xi\left(y_{o}, y_{i}\right)=\sum_{k=1}^{n} \omega_{k} \vartheta_{k}
$$

VI. Grey relational order: Once the GRG is computed, the highest value of the GRG is ranked as 1 . And, the rests are ordered as in descending order. The experiment number, ranked 1, is the optimum run.

\section{Results and discussion}

\subsection{Investigation}

Let us present a graphical representation of the influence of face milling parameters on tool wear and surface roughness $R z$. 


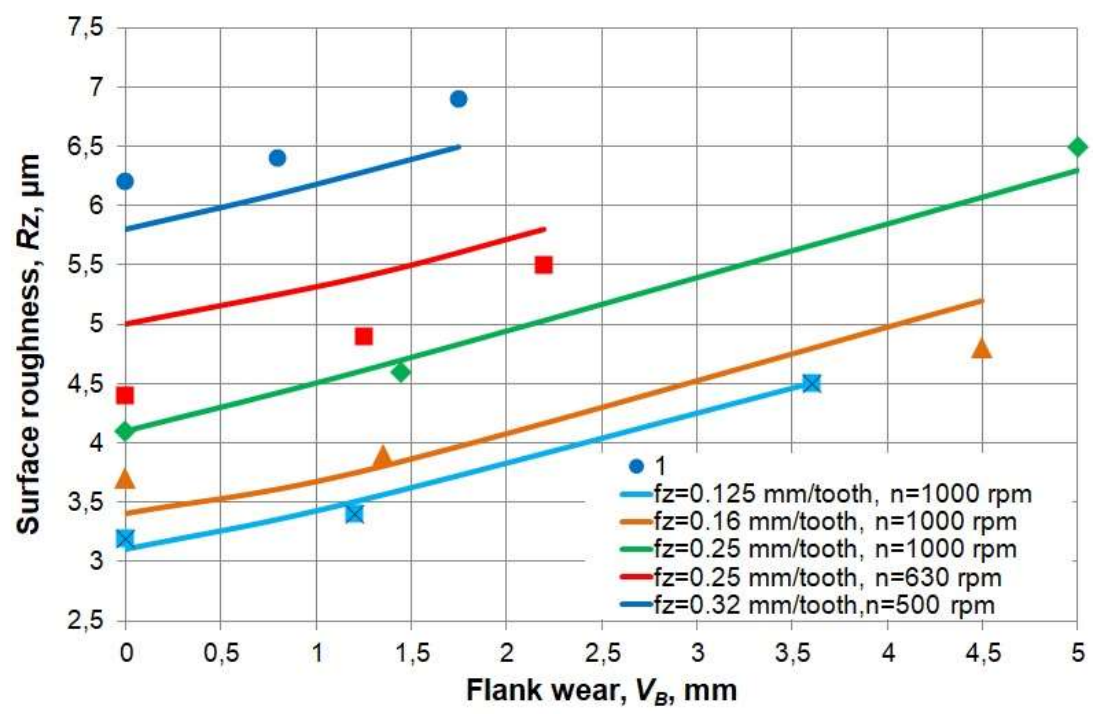

Fig. 2. Average experimental values of surface roughness $R z$ for various values of flank wear $V_{B}$ and various parameters in face milling at the milling depth $a_{p}=1.0 \mathrm{~mm}: 1-f_{z}=0.125 \mathrm{~mm} /$ tooth, $v_{c}=392.6$ $\mathrm{m} / \mathrm{min} ; 2-f_{z}=0.16 \mathrm{~mm} /$ tooth, $v_{c}=392.6 \mathrm{~m} / \mathrm{min} ; 3-f_{z}=0.25 \mathrm{~mm} /$ tooth, $v_{c}=392.6 \mathrm{~m} / \mathrm{min} ; 4-f_{z}=$ $0.25 \mathrm{~mm} /$ tooth, $v_{c}=247.6 \mathrm{~m} / \mathrm{min} ; 5-f_{z}=0.32 \mathrm{~mm} /$ tooth, $v_{c}=196.3 \mathrm{~m} / \mathrm{min}$.

Figure 2 demonstrates that the values of surface roughness $R z$ are different for various milling parameters. At the constant cutting speed $v_{c}=392.6 \mathrm{~m} / \mathrm{min}$ (corresponding to the Spindle rotation speed $n=1000 \mathrm{rpm})$, at the feed per tooth $f_{z}=0.125,0.16$ and $0.25 \mathrm{~mm} /$ tooth respectively for a sharp mill surface roughness $R z$ will be 3.2, 3.7 and $4.1 \mathrm{~mm}$ respectively (see Fig. 2). From the physical point of view, this can be explained by the fact that as the feed rate increases, the height of the ridges between the consecutive traces of the mill tooth cutting edge also increases1. At the constant feed per tooth $f_{z}=0.25 \mathrm{~mm} /$ tooth, as the cutting speed $v_{c}$ decreases from $392.6 \mathrm{~m} / \mathrm{min}$ (corresponding to the Spindle rotation speed $n=1000 \mathrm{rpm}$ ) to $24.6 \mathrm{~m} / \mathrm{min}$ (corresponding to the Spindle rotation speed $n=630 \mathrm{rpm}$ ) surface roughness $R z$ for the sharp cutting edge of the mill tooth decreases from 4.1 to 5.0 $\mathrm{mm}$ (see Fig. 2). From the physical point of view, this is caused by the fact that as the cutting speed increases, the temperature in the cutting zone also increases, so the chip comes off more smoothly, the crystals are not ripped off, and the microroughness is lower. At the feed per tooth $f_{z}=0.32$ $\mathrm{mm} /$ tooth and cutting speed $v_{c}=247.3 \mathrm{~m} / \mathrm{min}$ (corresponding to the Spindle rotation speed $n=500$ $\mathrm{rpm}$ ) surface roughness $R z$ for the sharp cutting edge of the mill tooth is at its maximum and equals $5.8 \mathrm{~mm}$ (see Fig 2). In this case, feed per tooth $f_{z}$ is the highest out of the five values, and the cutting speed is the lowest, all of which leads to an increase in $R z$.

The influence of the milling parameters on flank wear $V_{B}$ also varies. Maximum wear $V_{B}$ corresponds to two passes of the mill along the length of the workpiece $2 \times 200=400 \mathrm{~mm}$. For example, at the maximum cutting speed $v_{c}=392.6 \mathrm{~m} / \mathrm{min}(\mathrm{n}=1000 \mathrm{rpm})$ and feed rate $f_{z}=0.125 \mathrm{~mm} /$ tooth after two passes of the mill the flank wear $V_{B}=3.6 \mathrm{~mm}$, surface roughness $R z$ increases by $41 \%$ as compared to a sharp mill; at feed per tooth $f_{z}=0.16 \mathrm{~mm} /$ tooth after two passes of the mill the flank wear $V_{B}=4.5 \mathrm{~mm}$, and $R z$ is increased by $30 \%$; at feed per tooth $f_{z}=0.25 \mathrm{~mm} /$ tooth after two passes of the mill the flank wear $V_{B}=5.0 \mathrm{~mm}$, and $R z$ is increased by $59 \%$. So as feed rate $f_{z}$ increases from 0.125 to $0.25 \mathrm{~mm} /$ tooth at the same cutting speed, an increase flank wear $V_{B}$ from 3.6 to $5.0 \mathrm{~mm}$ is observed. From the physical point of view, this is explained by the fact that the sliding distance decreases as the feed rate increases $f_{z}$ from 0.125 to $0.25 \mathrm{~mm} /$ tooth (see Fig 3), but the area of contact between the cutting edge and the workpiece increases, which leads to an increase in the cutting force for both the main and the flank surfaces of the cutting edge of the mill tooth. Processing time also decreases (that is, efficiency increases) as the feed rate $f_{z}$ increases from 0.125 to $0.25 \mathrm{~mm} /$ tooth (Fig. 4). And at the constant feed per tooth $f_{z}=0.25 \mathrm{~mm} /$ tooth, as the cutting speed $v_{c}$ decreases from $392.6 \mathrm{~m} / \mathrm{min}$ (corresponding to the Spindle rotation speed $n=1000 \mathrm{rpm}$ ) to $247.6 \mathrm{~m} / \mathrm{min}$ (corresponding to the 
Spindle rotation speed $n=630 \mathrm{rpm}$ ) after two passes of the mill $V_{B}$ is 5.0 and $2.2 \mathrm{~mm}$ respectively, with $R z$ increased by $59 \%$ and $34 \%$ respectively as compared to a sharp mill. Milling at a higher speed leads to faster buildup of the flank wear of the mill tooth as the sliding distance increases significantly (see Fig. 3). Processing time also increases as the cutting speed vc increases from 392.6 to $247.6 \mathrm{~m} / \mathrm{min}$ (Fig. 4). At the feed per tooth $f_{z}=0.32 \mathrm{~mm} /$ tooth and the cutting speed $v_{c}=247.3 \mathrm{~m} / \mathrm{min}$ (corresponding to the Spindle rotation speed $n=500 \mathrm{rpm}$ ) after two passes of the mill $V_{B}=1.75 \mathrm{~mm}$, and $R z$ is increased by $11 \%$ as compared to a sharp mill (see Fig. 2). Sliding distance is at its minimum here out of the five sets of cutting parameters (see Fig. 3).

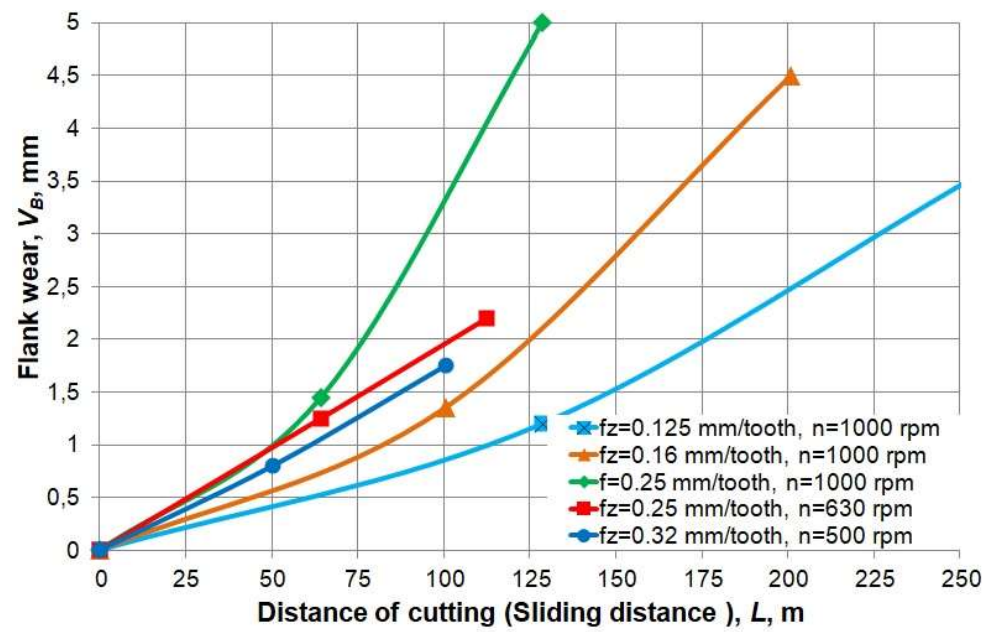

Fig. 3. Experimental values of the tool wear depending on the sliding distance at the milling depth $a_{p}$ $=1.0 \mathrm{~mm}: 1-f_{z}=0.125 \mathrm{~mm} /$ tooth, $v_{c}=392.6 \mathrm{~m} / \mathrm{min} ; 2-f_{z}=0.16 \mathrm{~mm} /$ tooth,$v_{c}=392.6 \mathrm{~m} / \mathrm{min} ; 3-f_{z}=$ $0.25 \mathrm{~mm} /$ tooth, $v_{c}=392.6 \mathrm{~m} / \mathrm{min} ; 4-f_{z}=0.25 \mathrm{~mm} /$ tooth, $v_{c}=247.6 \mathrm{~m} / \mathrm{min} ; 5-f_{z}=0.32 \mathrm{~mm} /$ tooth,$v_{c}=$ $196.3 \mathrm{~m} / \mathrm{min}$.

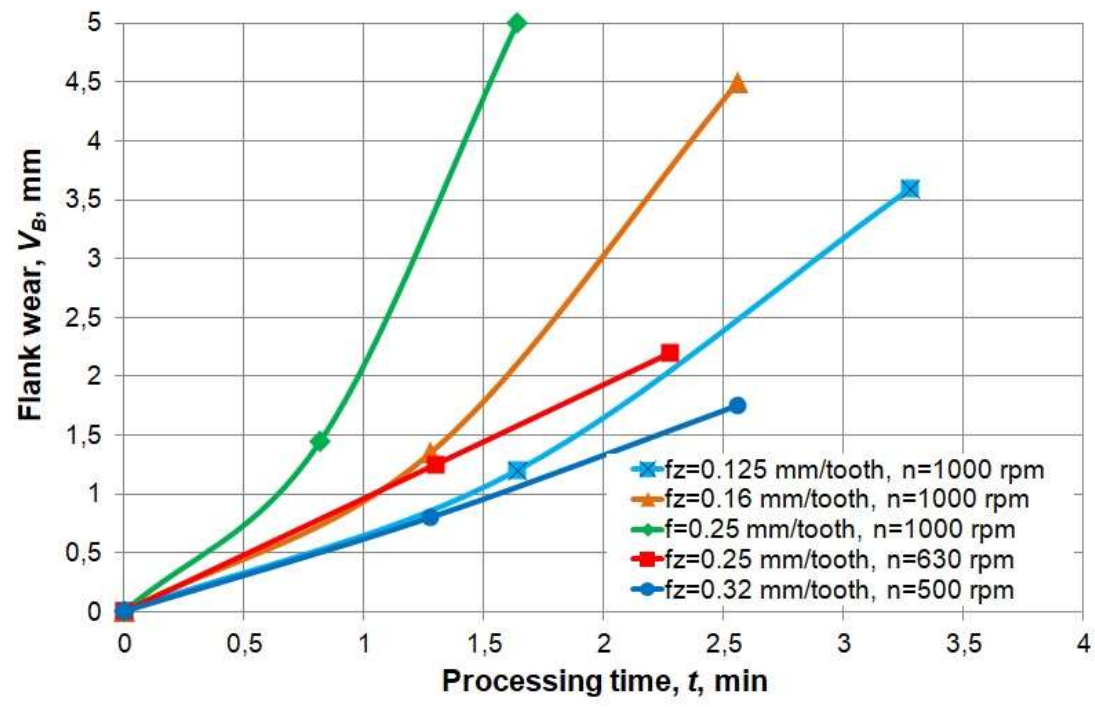

Fig. 4. Experimental values of the tool wear depending on the processing time at the milling depth $a_{p}$ $=1.0 \mathrm{~mm}: 1-f_{z}=0.125 \mathrm{~mm} /$ tooth,$v_{c}=392.6 \mathrm{~m} / \mathrm{min} ; 2-f_{z}=0.16 \mathrm{~mm} /$ tooth, $v_{c}=392.6 \mathrm{~m} / \mathrm{min} ; 3-f_{z}=$ $0.25 \mathrm{~mm} /$ tooth, $v_{c}=392.6 \mathrm{~m} / \mathrm{min} ; 4-f_{z}=0.25 \mathrm{~mm} /$ tooth, $v_{c}=247.6 \mathrm{~m} / \mathrm{min} ; 5-f_{z}=0.32 \mathrm{~mm} /$ tooth,$v_{c}=$ $196.3 \mathrm{~m} / \mathrm{min}$.

The influence of the milling parameters has therefore significant effect on characteristics such as surface roughness $R z$. 


\subsection{Optimization}

Following the methodology of Section 2.2, multiple responses i.e. roughness parameter, cost of part, power consumption, and material removal rate are simultaneously optimized using Grey relational analysis. The experimental/computed data of Table 3 are used in the optimization. The preprocessed sequence is developed by using Eq. 3, 4 (for $R z, C, P_{c}$ ) and using Eq. 5 (for MRR), and listed in Table 4.

Table 4. Preprocessing sequence.

\begin{tabular}{ccccc}
\hline Exp. No. & Roughness, $\boldsymbol{R z}$ & $\begin{array}{c}\text { The cost price of } \\
\text { processing one part, } \boldsymbol{C}\end{array}$ & Cutting power, $\boldsymbol{P}_{\boldsymbol{c}}$ & $\begin{array}{c}\text { Material removal } \\
\text { rate, MRR }\end{array}$ \\
\hline 1 & 1.0000 & 1.0000 & 1.0000 & 0.0000 \\
2 & 0.9459 & 0.5006 & 0.8195 & 0.0000 \\
3 & 0.6486 & 0.0000 & 0.4835 & 0.0000 \\
4 & 0.8649 & 1.0000 & 0.9178 & 0.2790 \\
5 & 0.8108 & 0.5006 & 0.7157 & 0.2790 \\
6 & 0.5676 & 0.0002 & 0.2814 & 0.2790 \\
7 & 0.7568 & 1.0000 & 0.7035 & 1.0000 \\
8 & 0.6216 & 0.5006 & 0.4821 & 1.0000 \\
9 & 0.1081 & 0.0006 & 0.0000 & 1.0000 \\
10 & 0.6757 & 1.0000 & 0.9477 & 0.2587 \\
11 & 0.5405 & 0.5570 & 0.8311 & 0.2587 \\
12 & 0.3784 & 0.2231 & 0.7534 & 0.2587 \\
13 & 0.1892 & 1.0000 & 0.9539 & 0.2790 \\
14 & 0.1351 & 0.6671 & 0.8894 & 0.2790 \\
15 & 0.0000 & 0.3338 & 0.8298 & 0.2790 \\
\hline
\end{tabular}

The deviation sequence, computed using ' 1 - Preprocessing sequence', is tabulated in Table 5.

Table 5. Deviation sequence.

\begin{tabular}{ccccc}
\hline Exp. No. & Roughness, $\boldsymbol{R z}$ & $\begin{array}{c}\text { The cost price of } \\
\text { processing one part, } \boldsymbol{C}\end{array}$ & Cutting power, $\boldsymbol{P}_{\boldsymbol{c}}$ & $\begin{array}{c}\text { Material removal } \\
\text { rate, MRR }\end{array}$ \\
\hline 1 & 0.0000 & 0.0000 & 0.0000 & 1.0000 \\
2 & 0.0541 & 0.4994 & 0.1805 & 1.0000 \\
3 & 0.3514 & 1.0000 & 0.5165 & 1.0000 \\
4 & 0.1351 & 0.0000 & 0.0822 & 0.7210 \\
5 & 0.1892 & 0.4994 & 0.2843 & 0.7210 \\
6 & 0.4324 & 0.9998 & 0.7186 & 0.7210 \\
7 & 0.2432 & 0.0000 & 0.2965 & 0.0000 \\
8 & 0.3784 & 0.4994 & 0.5179 & 0.0000 \\
9 & 0.8919 & 0.9994 & 1.0000 & 0.0000 \\
10 & 0.3243 & 0.0000 & 0.0523 & 0.7413 \\
11 & 0.4595 & 0.4430 & 0.1689 & 0.7413 \\
12 & 0.6216 & 0.7769 & 0.2466 & 0.7413 \\
13 & 0.8108 & 0.0000 & 0.0461 & 0.7210 \\
14 & 0.8649 & 0.3329 & 0.1106 & 0.7210 \\
15 & 1.0000 & 0.6662 & 0.1702 & 0.7210 \\
\hline
\end{tabular}


Later, the grey-relational coefficient is computed using Eq. 3 and listed in Table 6.

Table 6. Grey relational coefficient.

\begin{tabular}{ccccc}
\hline Exp. No. & Roughness, $\boldsymbol{R z}$ & $\begin{array}{c}\text { The cost price of } \\
\text { processing one part, } \boldsymbol{C}\end{array}$ & Cutting power, $\boldsymbol{P}_{\boldsymbol{c}}$ & $\begin{array}{c}\text { Material removal } \\
\text { rate, MRR }\end{array}$ \\
\hline 1 & 1.0000 & 1.0000 & 1.0000 & 0.3333 \\
2 & 0.9024 & 0.5003 & 0.7348 & 0.3333 \\
3 & 0.5873 & 0.3333 & 0.4919 & 0.3333 \\
4 & 0.7872 & 1.0000 & 0.8588 & 0.4095 \\
5 & 0.7255 & 0.5003 & 0.6375 & 0.4095 \\
6 & 0.5362 & 0.3334 & 0.4103 & 0.4095 \\
7 & 0.6727 & 1.0000 & 0.6278 & 1.0000 \\
8 & 0.5692 & 0.5003 & 0.4912 & 1.0000 \\
9 & 0.3592 & 0.3335 & 0.3333 & 1.0000 \\
10 & 0.6066 & 1.0000 & 0.9053 & 0.4028 \\
11 & 0.5211 & 0.5302 & 0.7475 & 0.4028 \\
12 & 0.4458 & 0.3916 & 0.6697 & 0.4028 \\
13 & 0.3814 & 1.0000 & 0.9155 & 0.4095 \\
14 & 0.3663 & 0.6003 & 0.8188 & 0.4095 \\
15 & 0.3333 & 0.4287 & 0.7461 & 0.4095 \\
\hline
\end{tabular}

For GRC, the distinguishing coefficient, $\varsigma=0.5$. At last, the Grey relational grade (GRG) is calculated by combining the GRCs of all the responses. The respective weights for the responses were determined from two perspectives. First, if the technologist is faced with the task of making the part with the greatest performance, the logical deduction is to emphasize on the product quality and on the material removal. That means the surface roughness and material removal rate are assigned higher weights than other two responses. As such, in the current study, case-1 has considered $w_{R z}=$ 1.0, $w_{c}=0.5, w_{c}=0.5$ and $w_{M R R}=1.0$. On the second case, if the main objective is to conserve resources maintaining product quality acceptable, then more importance is delegated to surface quality, cost of producing single part, and the consumption of power; and less weight is exerted on material removal rate. As such, the weights for case-2 are: $w_{R z}=1.0, w_{c}=1.0, w_{P_{c}}=1.0$ and $w_{M R R}=0.5$. Note that in both cases the product quality was not compromised.

Table 7 shows the GRG and respective rank for both cases. For case-1, the experiment number 7 is found as the optimum run; the corresponding input parameters for this case are: feed per tooth $f_{z}=$ $0.25 \mathrm{~mm} /$ tooth, cutting speed $v_{c}=392.6 \mathrm{~m} / \mathrm{min}$, cutting length $l=0.5 \mathrm{~mm}$. For case- 2 , the optimum parameters values are: feed per tooth $f_{z}=0.125 \mathrm{~mm} /$ tooth, cutting speed $v_{c}=392.6 \mathrm{~m} / \mathrm{min}$, cutting length $l=0.5 \mathrm{~mm}$. Therefore, it is visible that the change in the requirements from 'performance' to 'resource conservation' has entailed a different optimum result; here, the cutting speed and cutting length though are same, the feed per tooth is reduced from 0.25 to $0.125 \mathrm{~mm} /$ tooth. 
Table 7. Grey relational grade and rank.

\begin{tabular}{ccccc}
\hline Exp. No. Case-1: $w_{R z}=\mathbf{1 . 0}, w_{c}=\mathbf{0 . 5}, w_{P_{c}=\mathbf{0 . 5},} w_{M R R}=\mathbf{1 . 0}$ & Case-2: $w_{R z}=\mathbf{1 . 0}, w_{c}=\mathbf{1 . 0}, w_{P_{c}}=\mathbf{1 . 0}$ and $w_{M R R}$ \\
\cline { 2 - 5 } & Grey relational grade & Rank & Grey relational grade & Rank \\
\hline 1 & 0.7778 & 2 & $\mathbf{0 . 9 0 4 8}$ & $\mathbf{1}$ \\
2 & 0.6178 & 6 & 0.6583 & 6 \\
3 & 0.4444 & 13 & 0.4512 & 13 \\
4 & 0.7087 & 3 & 0.8145 & 2 \\
5 & 0.5680 & 8 & 0.5909 & 7 \\
6 & 0.4392 & 15 & 0.4242 & 15 \\
7 & $\mathbf{0 . 8 2 8 9}$ & $\mathbf{1}$ & 0.8001 & 3 \\
8 & 0.6883 & 4 & 0.5888 & 8 \\
9 & 0.5642 & 8 & 0.4360 & 14 \\
10 & 0.6540 & 5 & 0.7752 & 4 \\
11 & 0.5209 & 10 & 0.5715 & 9 \\
12 & 0.4597 & 12 & 0.4881 & 12 \\
13 & 0.5829 & 7 & 0.7148 & 5 \\
14 & 0.4951 & 11 & 0.5686 & 10 \\
15 & 0.4434 & 14 & 0.4894 & 11 \\
\hline
\end{tabular}

Bold numbers indicate the optimum runs.

\section{Conclusions}

The research conducted has shown that:

Surface roughness values $R z$ for various milling parameters vary: increasing feed per tooth at the constant cutting speed leads to an increase in surface roughness; decreasing the cutting speed at the constant feed per tooth also leads to an increase in surface roughness. As the flank wear area $V_{B}$ increases, surface roughness $R z$ also does.

Multi-objective optimization using Gray Relational Analysis (GRA) showed that the optimum parameters for improving the manufacturing efficiency and reduce the machining time (case 1) are as follows: feed per tooth $f_{z}=0.25 \mathrm{~mm} /$ tooth, cutting speed $v_{c}=392.6 \mathrm{~m} / \mathrm{min}$ and cutting length $l=0.5$ $\mathrm{mm}$; for resource saving (case 2), the optimum parameters are: feed per tooth $f_{z}=0.125 \mathrm{~mm} /$ tooth, cutting speed $v_{c}=392.6 \mathrm{~m} / \mathrm{min}$, cutting length $l=0.5 \mathrm{~mm}$.

Author Contributions: Conceptualization, D.Y.P. and M.K.G.; Methodology, D.Y.P. and M.K.G.; Software, M.K.G.; Validation, M.K.G., A.T.A., M.S.S. and M.M.E.R; Formal Analysis, D.Y.P., M.K.G., M.S.S. and M.M.E.R.; Investigation, D.Y.P., M.K.G., I.N.E., A.T.A., M.S.S. and M.M.E.R.; Resources, D.Y.P., M.K.G. and I.N.E.; Data Curation, D.Y.P., M.K.G. and I.N.E.; Writing-Original Draft Preparation, D.Y.P., M.K.G. and I.N.E.; Writing-Review \& Editing, D.Y.P., M.K.G., I.N.E. A.T.A., M.S.S. and M.M.E.R.; Visualization, D.Y.P. and M.K.G.; Supervision, D.Y.P., M.K.G., I.N.E., A.T.A., M.S.S. and M.M.E.R; Project Administration, D.Y.P. and A.T.A.; Funding Acquisition, D.Y.P. and A.T.A.

Acknowledgments: The authors extend their appreciation to the Deanship of Scientific Research at King Saud University for funding this work through research group No (RG-1439-020). The research was also supported through Act 211 Government of the Russian Federation, contract Nr 02.A03.21.0011.

Conflicts of Interest: The authors declare no conflict of interest. 


\section{References}

1. Annual Energy Review - Energy Information Administration, 2011: https://www.eia.gov/totalenergy/data/annual (accessed on 2011)

2. Pimenov, D.Yu.; Guzeev, V.I.; Krolczyk, G.; Mia, M.; Wojciechowski, S. Modeling flatness deviation in face milling considering angular movement of the machine tool system components and tool flank wear. Precis. Eng. 2018, 54, 327-337, https://doi.org/10.1016/j.precisioneng.2018.07.001

3. Pimenov, D.Yu.; Bustillo, A.; Mikolajczyk, T. Artificial intelligence for automatic prediction of required surface roughness by monitoring wear on face mill teeth. J. Intell. Manuf. 2018, 29(5), 1045-1061, https://doi.org/10.1007/s10845-017-1381-8

4. Wojciechowski, S.; Maruda, R.W.; Nieslony, P.; Krolczyk, G.M. Investigation on the edge forces in ball end milling of inclined surfaces. Int. J. Mech. Sci. 2016, 119, 360-369, https://doi.org/10.1016/j.ijmecsci.2016.10.034

5. Fratila, D.; Caizar, C. Application of Taguchi method to selection of optimal lubrication and cutting conditions in face milling of AlMg3. J. Clean. Prod. 2011, 19(6-7), 640-645, https://doi.org/10.1016/j.jclepro.2010.12.007

6. Simunovic, K.; Simunovic, G.; Saric, T. Single and multiple goal optimization of structural steel face milling process considering different methods of cooling/lubricating. J. Clean. Prod. 2015, 94, 321-329, https://doi.org/10.1016/j.jclepro.2015.02.015

7. Wang, C.; Li, K.; Chen, M.; Liu, Z. Evaluation of minimum quantity lubrication effects by cutting force signals in face milling of Inconel 182 overlays. J. Clean. Prod. 2014, 108, https://doi.org/10.1016/j.jclepro.2015.06.095

8. Kundrák, J.; Markopoulos, A.P.; Makkai, T.; Karkalos, N.E. Correlation between process parameters and cutting forces in the face milling of steel. Lect. Not. Mech. Eng. 2018, (9783319756769), 255-267, https://doi.org/10.1007/978-3-319-75677-6_21

9. Jersák, J.; Simon, S. Influence of cooling lubricants on the surface roughness and energy efficiency of the cutting machine tools. Int. J. Appl. Mech. Eng. 2017, 22(3), 779-787, https://doi.org/10.1515/ijame-2017-0050

10. Mikołajczyk, T.; Nowicki, K.; Kłodowski, A.; Pimenov, D.Yu. Neural network approach for automatic image analysis of cutting edge wear. Mech. Syst. Signal Process. 2017, 88, 100-110, https://doi.org/10.1016/j.ymssp.2016.11.026

11. Machado, Á.R.; Diniz, A.E. Tool wear analysis in the machining of hardened steels. Int. J. Adv. Manuf. Technol. 2017, 92(9-12), 4095-4109, https://doi.org/10.1007/s00170-017-0455-2

12. Li, C.; Chen, X.; Tang, Y.; Li, L. Selection of optimum parameters in multi-pass face milling for maximum energy efficiency and minimum production cost. J. Clean. Prod. 2017, 140, 1805-1818, https://doi.org/10.1016/j.jclepro.2016.07.086

13. Wang, Y.-C.; Kim, D.-W.; Katayama, H.; Hsueh, W.-C. Optimization of machining economics and energy consumption in face milling operations. Int. J. Adv. Manuf. Technol. 2018, 99(9-12), 2093-2100, https://doi.org/10.1007/s00170-018-1848-6

14. Pimenov, D.Yu. Experimental research of face mill wear effect to flat surface roughness. J. Frict. Wear 2014, 35(3), 250-254, https://doi.org/10.3103/S1068366614030118

15. Suárez, A.; Veiga, F.; de Lacalle, L.N.L.; Polvorosa, R.; Lutze, S.; Wretland, A. Effects of Ultrasonics-Assisted Face Milling on Surface Integrity and Fatigue Life of Ni-Alloy 718. J. Mater. Eng. Perform. 2016, 25(11), 5076-5086, https://doi.org/10.1007/s11665-016-2343-6

16. Hu, L.; Peng, C.; Evans, S.; Peng, T.; Liu, Y.; Tang, R.; Tiwari, A. Minimising the machining energy consumption of a machine tool by sequencing the features of a part. Energy 2017, 121, 292-305, https://doi.org/10.1016/j.energy.2017.01.039

17. Hu, L.; Liu, Y.; Peng, C.; Tang, W.; Tang, R.; Tiwari, A. Minimising the energy consumption of tool change and tool path of machining by sequencing the features. Energy 2018, 147, 390-402, https://doi.org/10.1016/j.energy.2018.01.046

18. Li, L.; Yan, J.; Xing, Z. Energy requirements evaluation of milling machines based on thermal equilibrium and empirical modelling. J. Clean. Prod. 2013, 52, 113-121, https://doi.org/10.1016/j.jclepro.2013.02.039

19. Aramcharoen, A.; Mativenga, P.T. Critical factors in energy demand modelling for CNC milling and impact of toolpath strategy. J. Clean. Prod. 2014, 78, 63-74, https://doi.org/10.1016/j.jclepro.2014.04.065 
20. Garg, A.; Lam, J.S.L.; Gao, L. Energy conservation in manufacturing operations: modelling the milling process by a new complexity-based evolutionary approach. J. Clean. Prod. 2015, 108, 34-45, https://doi.org/10.1016/j.jclepro.2015.06.043

21. Albertelli, P.; Keshari, A.; Matta, A. Energy oriented multi cutting parameter optimization in face milling. J. Clean. Prod. 2016, 137, 1602-1618, https://doi.org/10.1016/j.jclepro.2016.04.012

22. Garg, A.; Lam, J.S.L.; Gao, L. Power consumption and tool life models for the production process. J. Clean. Prod. 2016, 131, 754-764, https://doi.org/10.1016/j.jclepro.2016.04.099

23. Shin, S.-J.; Woo, J.; Rachuri, S. Energy efficiency of milling machining: Component modeling and online optimization of cutting parameters. J. Clean. Prod. 2017, 161, 12-29, https://doi.org/10.1016/j.jclepro.2017.05.013

24. Deng, Z.; Zhang, H.; Fu, Y.; Wan, L.; Liu, W. Optimization of process parameters for minimum energy consumption based on cutting specific energy consumption. J. Clean. Prod. 2017, 166, 1407-1414, https://doi.org/10.1016/j.jclepro.2017.08.022

25. Shi, K.N.; Zhang, D.H.; Liu, N.; Wang, S.B.; Ren, J.X.; Wang, S.L. A novel energy consumption model for milling process considering tool wear progression. J. Clean. Prod. 2017, 184, 152-159, https://doi.org/10.1016/j.jclepro.2018.02.239

26. Lv, J.; Tang, R.; Tang, W.; Jia, S.; Liu, Y.; Cao, Y. An investigation into methods for predicting material removal energy consumption in turning. J. Clean. Prod. 2018, 193, 128-139, https://doi.org/10.1016/j.jclepro.2018.05.035

27. Altıntaş, R.S.; Kahya, M.; Ünver, H.ÖModelling and optimization of energy consumption for feature based milling. Int. J. Adv. Manuf. Technol. 2016, 86(9), 3345-3363, https://doi.org/10.1007/s00170-016-8441-7

28. Yang, W.-a.; Guo, Y.; Liao, W. Multi-objective optimization of multi-pass face milling using particle swarm intelligence. Int. J. Adv. Manuf. Technol. 2011, 56(5), 429-443, https://doi.org/10.1007/s00170-011-3187-8

29. Yang, Y.; Li, X.; Gao, L.; Shao, X. Modeling and impact factors analyzing of energy consumption in CNC face milling using GRASP gene expression programming. Int. J. Adv. Manuf. Technol. 2016, 87(5), 1247-1263, https://doi.org/10.1007/s00170-013-5017-7

30. Sales, W.; Becker, M.; Barcellos, C.S.; Landre, Jr J.; Bonney, J.; Ezugwu, E.O. Tribological behaviour when face milling AISI 4140 steel with minimum quantity fluid application. Ind. Lubric. Tribol. 2009, 61(2), 84-90, https://doi.org/10.1108/00368790910940400

31. Singh, G.R.; Gupta, M.K.; Mia, M.; Sharma, V.S. Modeling and optimization of tool wear in MQL-assisted milling of Inconel 718 superalloy using evolutionary techniques. Int. J. Adv. Manuf. Technol. 2018, 97(1-4), 481-494, https://dx.doi.org/10.1007/s00170-018-1911-3

32. Gupta, M.K.; Pruncu, C.I.; Mia, M.; Singh, G.; Singh, S.; Prakash, C.; Sood, P.K.; Gill, H.S. Machinability Investigations of Inconel-800 Super Alloy under Sustainable Cooling Conditions. Materials 2018, 11, 2088, https://doi.org/10.3390/ma11112088

33. Siller, H.R.; Vila, C.; Rodríguez, C.A.; Abellán, J.V. Study of face milling of hardened AISI D3 steel with a special design of carbide tools. Int. J. Adv. Manuf. Technol. 2009, 40(1), 12-25, https://doi.org/10.1007/s00170-007-1309-0

34. Cui, X.; Zhao, J. Cutting performance of coated carbide tools in high-speed face milling of AISI H13 hardened steel. Int. J. Adv. Manuf. Technol. 2014, 71(9-12), 1811-1824, https://doi.org/10.1007/s00170-014-5611-3

35. Houchuan, Y.; Zhitong, C.; ZiTong, Z. Influence of cutting speed and tool wear on the surface integrity of the titanium alloy Ti-1023 during milling. Int. J. Adv. Manuf. Technol. 2015, 78(5-8), 1113-1126, https://doi.org/10.1007/s00170-014-6593-x

36. Liu, G.; Zou, B.; Huang, C.; Wang, X.; Wang, J.; Liu, Z. Tool damage and its effect on the machined surface roughness in high-speed face milling the 17-4PH stainless steel. Int. J. Adv. Manuf. Technol. 2016, 83(1-4), 257-264, https://doi.org/10.1007/s00170-015-7564-6

37. Bruni, C.; d'Apolito, L.; Forcellese, A.; Gabrielli, F.; Simoncini, M. Surface roughness modelling in finish face milling under MQL and dry cutting conditions. Int. J. Mater. Form. 2008, 1(1), 503-506, https://doi.org/10.1007/s12289-008-0151-8

38. Sahu, N.K.; Andhare, A.B. Modelling and multiobjective optimization for productivity improvement in high speed milling of Ti-6Al-4V using RSM and GA. J. Braz. Soc. Mech. Sci. Eng. 2017, 39(12), 5069-5085, https://doi.org/10.1007/s40430-017-0804-y 
39. Siwawut, S.; Saikaew, C.; Wisitsoraat, A.; Surinphong, S. Cutting performances and wear characteristics of WC inserts coated with TiAlSiN and CrTiAlSiN by filtered cathodic arc in dry face milling of cast iron. Int. J. Adv. Manuf. Technol. 2018, 97(9), 3883-3892, https://doi.org/10.1007/s00170-018-2200-x

40. Pimenov, D.Yu. Mathematical modeling of power spent in face milling taking into consideration tool wear. J. Frict. Wear 2015, 36(1), 45-48, https://doi.org/10.3103/S1068366615010110

41. Guzeev, V.I.; Pimenov, D.Yu. Cutting force in face milling with tool wear. Russ. Eng. Res. 2011, 31(10), 989-993, https://doi.org/10.3103/S1068798X11090139

42. Pimenov, D.Yu.; Guzeev, V.I. Mathematical model of plowing forces to account for flank wear using FME modeling for orthogonal cutting scheme. Int. J. Adv. Manuf. Technol. 2017, 89(9-12), 3149-3159, https://doi.org/10.1007/s00170-016-9216-x

43. D'yakonov, A.A. Improvement of grinding speeds by assessing the machinability of materials. Russ. Eng. Res. 2012, 32(7-8), 604-607, https://dx.doi.org/10.3103/S1068798X12060068

44. Pimenov, D.Y.; Guzeev, V.I.; Koshin, A.A.Influence of cutting conditions on the stress at tool's rear surface. Russ. Eng. Res. 2011, 31(11), 1151-1155, https://dx.doi.org/10.3103/S1068798X11110207 